\title{
Dynamic Loads and Different Soil Characteristics Examination on Optimum Design of Cantilever Retaining Walls Utilizing Harmony Search Algorithm
}

\author{
Esra Uray ${ }^{a^{*}}$, Serdar Çarbaş ${ }^{a, b}$ \\ ${ }^{a}$ KTO Karatay University, Konya, Türkiye \\ ${ }^{b}$ Karamanoglu Mehmetbey University, Karaman, Türkiye

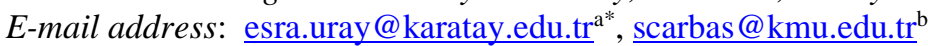 \\ ORCID numbers of authors: \\ 0000-0002-1121-2880, 0000-0002-3612-0640
}

Received date: 07.12.2021

Accepted date: 29.12 .2021

\begin{abstract}
Optimum the cantilever retaining wall design for different soils and dynamic earthquake effects is presented here. In the investigation of optimum wall design-based metaheuristic, the harmony search algorithm was considered for different design cases which include five soil and two earthquake characteristics. Earthquake characteristics of mild and severe were obtained regarding two locations which was selected from Turkey Earthquake Risk Map. For selected two locations and local soil classes, map spectral acceleration coefficients were utilized defined in Turkish Building Earthquake Code-2018. Sliding, overturning, and bearing capacity safety factors were taken as design constraints for checking stability criteria of the cantilever retaining wall which is given in Turkish Building Earthquake Code-2018. Since the cost-based wall weight of the optimization problem was taken as the objective function, obtained optimum wall dimensions which are discrete design variables were compared in terms of different design cases. It is seen that the wall dimensions increase in order to meet the design criteria in case of the earthquake load increases when the obtained optimum design by the optimization analyzes are examined. Another result obtained for the same earthquake zone is that the wall dimensions and therefore the cost mostly increase in weak quality soils.
\end{abstract}

Keywords: Cantilever retaining wall optimum design; Seismic design; Harmony search algorithm; Turkish Building Earthquake Code-2018; TBEC-18

\section{Introduction}

Retaining structures which is satisfied the stability between two different soil levels have a widespread application in geotechnical engineering, especially in safe transportation on highways or railways and construction in deep excavations as shoring. In the design of the cantilever retaining wall, which is one of the retaining structures, parameters like soil properties, groundwater condition, occurred lateral loads with the effect of static and dynamic, soil stratification, construction time, building usage purpose, and so on should be considered. In traditional cantilever wall design that stability criteria like safety factors of sliding, overturning, bearing capacity, etc. are calculated according to pre-dimensions of the wall, until suggested safety factors in literature are satisfied stability analyses continue [1]. Because conducting design by considering many parameters and design criteria like the above mentioned is challenging, the design of the retaining wall turns into a complex engineering design problem. Instead of traditional design based on run-error method, which is time-consuming and 
economical solution is not guaranteed, algorithm-based methods which enable to obtain the optimum solution of the retaining wall in a short time are widely used today in the solution of complex engineering design problems.

Another criterion is whether economic and environmentally friendly design is obtained optimum wall designs among vast combinations cluster formed by wall dimensions. The construction of the minimum weight retaining wall with optimum dimensions not only causes less cost but also provides less carbon dioxide emissions due to the required fewer materials. In the study conducted by Uray et.al. [2], a pre-dimension guide of cantilever retaining wall which gives safe and optimum designs was presented with harmony search optimization algorithm based.

Optimum designs of cantilever retaining walls have been acquired by many researchers utilizing metaheuristic optimization algorithms inspired by nature [3-10]. The dynamic load effect in cantilever retaining wall design is a situation that should be considered for designs to be made in earthquake zones. In the design of retaining walls, many studies have been conducted in which the design criteria specified in the Turkish Building Earthquake Code-2018 [11] were taken into account for the earthquake effect [12-15] and stability verifications for control the design criteria by considering the retaining wall-soil interaction in the earthquake effect are given in these studies. It is possible to meet studies in the literature that present optimum design of retaining walls by considering dynamic earthquake loads [16-21]. Harmony search optimization algorithm is an alternative manner obtaining optimum designs of retaining walls as it is seen from to an extensive literature review about reinforced concrete structural design optimization was given in the study conducted by Afzal et.al. [22]. In the study by Kalyoncuoğlu [23], that the acceleration records measured in different soil types subject to the same earthquake load were examined, having a different dynamic reaction considering each soil type within itself has been reported. For this reason, this study is aimed to investigate the effect of different soil types on the optimum structure design in regions with different earthquake effects.

In this study, the optimum design of the cantilever retaining wall for two different earthquake zones by regarding map spectral acceleration coefficients, Ss (for 0.25 and 1.50) and five local soil classes (ZA, ZB, ZC, ZD and ZE) selected from the Turkey Earthquake Hazard Map (TERM) [24] was investigated utilizing the harmony search algorithm presented by Geem et. al. [25]. In order to obtain optimum wall designs that ensure the stability of the cantilever retaining wall, the design criteria specified in the Turkish Building Earthquake Code-2018 (TBEC-18) [11] were taken into account. Obtained optimum designs of cantilever retaining walls for the different cases have been evaluated in terms of soil properties and earthquake effects by considering the cost.

\section{Design of Cantilever Retaining Wall under Static and Dynamics Loads}

\subsection{Turkish Building Earthquake Code-2018}

In cantilever retaining wall design, stability criteria like sliding and overturning of the wall, and carrying loads transfers from to wall to the soil through wall foundation should be satisfied under the effects of static and dynamic loads. While the static effect is occurred by lateral soil loads, surcharge loads, and so on, earthquakes cause dynamic loads owing to soil-structure interaction (Fig.1). For safe design, the safety factors of sliding, overturning, and bearing 
capacity obtained according to the loads that the wall is exposed to should be greater than the safety factor accepted in the literature [1]. In this study, the investigation of the optimum cantilever retaining wall (CRW) design is performed by considering the Turkish Building Earthquake Code-2018 (TBEC-18) [11].

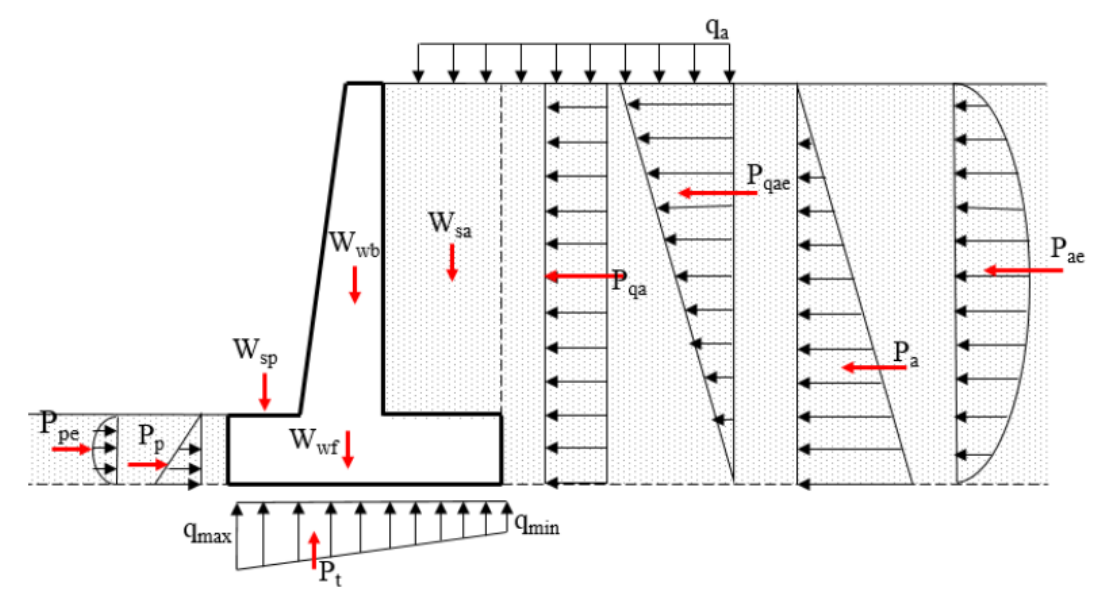

Fig.1. Acting static and dynamic loads on the cantilever retaining wall [14]

Since dynamic loads due to earthquake effect are transmitted to the wall through the soil, soil characteristics and location of the site where construct the wall are important determining of dynamic effects. The earthquake effect is affected by the horizontal $\left(\mathrm{k}_{\mathrm{h}}\right)$ and vertical $\left(\mathrm{k}_{\mathrm{v}}\right)$ acceleration coefficients on the wall (Eq.1).

$$
k_{h}=\frac{0.4 S_{D S}}{r} \quad k_{v}=0.5 k_{h}
$$

Here, while $S_{D S}$ is defined as design spectral response acceleration at short periods, $r$ is a coefficient based on the type of the wall and allowable displacement. In the optimization analyses, the $r$ coefficient was taken as 1.5 from TBDY-2018 for the retaining structure, which was designed taking into account the allowable displacement after the earthquake, so as not to damage the structural functions.

Total soil pressure resultant which is included static and dynamic loads acting on the wall is calculated by using Eq. 2.

$$
P_{t}=K\left(1 \mp k_{v}\right)\left(\frac{1}{2} \gamma^{*} H^{2}+q H\right)+P_{\text {water }}+\Delta P_{\text {water }}
$$

Here, $\mathrm{K}$ is the total (static+dynamic) soil pressure coefficient which is included active $\left(\mathrm{K}_{\mathrm{a}}\right)$ or passive $\left(K_{p}\right)$ cases, $q$ is the surcharge load, $H$ is the wall height, $\gamma^{*}$ is the typical unit weight, $\mathrm{P}_{\text {water }}$ and $\Delta \mathrm{P}_{\text {water }}$ show the resultant static and dynamic water pressures. $\mathrm{K}_{\mathrm{a}}$ and $\mathrm{K}_{\mathrm{p}}$ coefficients are calculated with the formulations given in TBEC- 18 .

The sliding safety factor of CRW under the effect of static loading is determined by using Eq.3. Here, $H_{s}$ is the stem height of the wall, $D_{b}$ is the wall foundation thickness, $P_{a s}$ is the active horizontal soil force in case of static loading, $\mathrm{P}_{\mathrm{ps}}$ is the passive soil force along with the foundation depth, B is the wall foundation width. 


$$
\begin{aligned}
& F_{s s}=\frac{\left(\Sigma V \tan \left(2 / 3 \phi_{t}\right)+2 / 3 c_{t} B+P_{p s}\right)}{P_{a s h}} \\
& P_{a s}=K_{a}\left[q\left(H_{s}+D_{b}\right)+0.5 \gamma_{d}\left(H_{s}+D_{b}\right)^{2}\right] \quad P_{a s h}=P_{a s} \cos \beta \quad P_{a s v}=P_{a s} \sin \beta \\
& P_{p s}=0.5 K_{p} \gamma_{d} D_{b}^{2}+2 c_{d} \sqrt{K_{p}} D_{b} \quad \Sigma V=W_{w b}+W_{w f}+W_{s a}+W_{s p}+P_{a s v}
\end{aligned}
$$

According to TBEC-18 the design horizontal force $\left(\mathrm{V}_{\text {th }}\right)$ acting on the foundation base should be less than the sum of the design frictional resistance $\left(\mathrm{R}_{\mathrm{th}}\right)$ and the design passive resistance $\left(\mathrm{R}_{\mathrm{pt}}\right)$ weighted by 0.3 , in order to ensure the sliding safety factor of CRW under the effect of dynamic earthquake load (Eq.4).

$$
\begin{aligned}
& V_{t h} \leq R_{t h}+0.3 R_{p t} \quad V_{t h}=P_{a s h}+\Delta P_{a e h}+\sum V k_{h} \\
& \Delta P_{a e}=P_{t}-P_{a s} \quad \Delta P_{a e h}=\Delta P_{a e} \cos \beta \quad \Delta P_{a e v}=\Delta P_{a e} \sin \beta \\
& P_{t}=K\left(1 \pm k_{v}\right)\left[\frac{1}{2} \gamma^{*} H^{2}+q H\right]+P_{s u}+\Delta P_{s u} \quad R_{t h}=\frac{P}{t v} \tan \delta_{\gamma_{R h}}^{(\text {drained })} \\
& R_{t h}={\frac{A_{c} c_{u}}{\gamma_{R h}}}_{\begin{array}{c}
\text { (undrained } \\
\text { cohesionless })
\end{array}} \quad R_{p t}=\frac{R_{p k}}{\gamma_{R p}} \quad R_{p k}=K_{p}\left(1-k_{v}\right)\left(0.5 \gamma D^{2}\right)
\end{aligned}
$$

The overturning safety factor used for static loading is given by Eq.5.

$$
F_{d s}=\frac{\Sigma M_{r}}{\Sigma M_{o}} \quad \Sigma M_{r}=\Sigma W_{i} x_{i}+P_{a s v} B \quad \Sigma M_{o}=0.5 K_{a}\left[q(H+D)^{2} \cos \beta+\gamma_{d}(H+D)^{3} / 3\right]
$$

Verification of overturning of cantilever retaining wall under dynamic effect is done by Eq.6.

$$
\gamma_{\text {Rdev }}=\frac{R_{d e v}}{E_{d e v}} \geq 1.3
$$

Here, $R_{\text {dev }}$ is the sum of the moments resisting overturning and $E_{d e v}$ is the sum of the moments trying to overturn.

In case of static loading, in the determination of bearing capacity, the maximum stress $\left(\mathrm{q}_{\max }\right)$ on the foundation soil must be less than the allowable safe foundation soil bearing capacity $\left(\mathrm{q}_{\mathrm{a}}\right)$ and the minimum stress ( $\mathrm{q}_{\min }$ ) must be greater than zero (Eq.7)

$$
q_{\max } \leq q_{a} \quad q_{a}=\frac{q_{u}}{3} \quad q_{\min } \geq 0 \quad q_{\substack{\max \\ \text { min }}}=\frac{\Sigma V}{B}\left(1 \pm \frac{6 e}{B}\right) \quad e=\frac{B}{2}-\frac{\Sigma M_{r}-\Sigma M_{o}}{\Sigma V}
$$

The ultimate soil bearing capacity, $\mathrm{q}_{\mathrm{a}}$, is obtained by dividing the calculated foundation soil bearing capacity $\left(\mathrm{q}_{\mathrm{u}}\right)$ by a certain safety factor [1]. The foundation soil bearing capacity $\left(\mathrm{q}_{\mathrm{u}}\right)$ can be determined using the overall bearing capacity proposed by Meyerhof [26]. In case of loading involving earthquake effect, the bearing capacity verification should meet the criteria given in Eq.8. 


$$
q_{o} \leq q_{t} \quad q_{t}=\frac{q_{k}}{\gamma_{R v}}
$$

Here, $\mathrm{q}_{\mathrm{o}}$ is the foundation base pressure formed by the vertical load, shear force and moment effects at the foundation level, and $\gamma_{\mathrm{Rv}}$ is the strength coefficient for the foundation overflow force given in TBEC-2018. Considered input parameters have been tabulated in Table 1 for optimization of CRW design

Table 1. Input parameters for optimization analyses of CRW

\begin{tabular}{cccc}
\hline Input parameters & Symbol & Value & Unit \\
\hline Stem height & $\mathrm{H}$ & 6 & $\mathrm{~m}$ \\
Surcharge load & $\mathrm{q}$ & 0 & $\mathrm{kPa}$ \\
Backfill slope & $\beta$ & 0 & $\circ$ \\
Undrained shear strength of base soil & $\mathrm{c}_{\mathrm{u}}$ & 250 & $\mathrm{kPa}$ \\
Unit weight of base soil & $\gamma_{\mathrm{b}}$ & 19 & $\mathrm{kPa}$ \\
Cohesion of base soil & $\mathrm{c}$ & 70 & $\mathrm{kPa}$ \\
Internal friction angle of the base soil & $\emptyset_{\mathrm{b}}$ & 25 & $\circ$ \\
Cohesion of backfill soil & $\mathrm{c}_{\mathrm{r}}$ & 0 & $\mathrm{kPa}$ \\
Depth of soil in front of the wall & $\mathrm{D}_{\mathrm{f}}$ & 1.5 & $\mathrm{~m}$ \\
Sliding and overturning safety factors & $\mathrm{SF}_{\mathrm{ss}}$ and SFso & 1.50 & - \\
The factor of safety for bearing capacity & $\mathrm{SF}_{\mathrm{sb}}$ & 3.00 & - \\
Unit weight of concrete & $\gamma_{\mathrm{c}}$ & 24 & $\mathrm{kPa}$ \\
\hline
\end{tabular}

\subsection{Design Cases}

In this study, optimum design of CRW has been investigated for selected two locations from Turkey Earthquake Risk Map (TERM) [24] which is show in Fig.2.

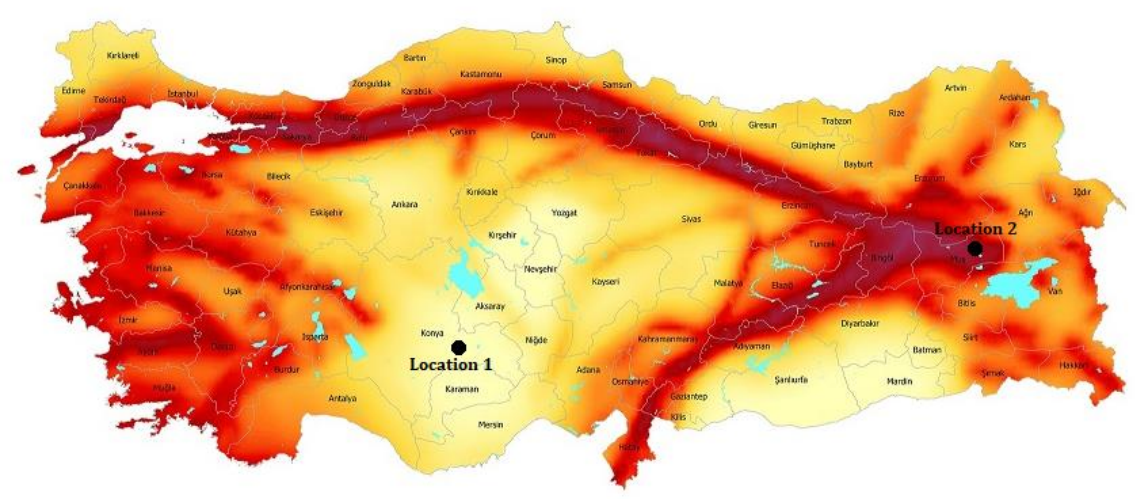

Fig.2. Selected locations from Turkey Earthquake Hazard Map (TERM) [24]

Design cases of different type of earthquake have been formed by using earthquake effect information for location 1 and location 2 obtained from TERM and local soil effect coefficients for the short period region (Fs) in TBEC-18. For the earthquake soil motion level DD-2, the seismicity of the region has been taken into account in the effect of earthquake loading on the CRW. For effect of severe earthquake and mild earthquake on the wall, the map spectral 
acceleration coefficients (Ss) have been taken as 1.50 and 0.25 , respectively. Different design cases are demonstrated in Table 2.

Table 2. Design cases

\begin{tabular}{ccccccccccc}
\hline Case & 1 & 2 & 3 & 4 & 5 & 6 & 7 & 8 & 9 & 10 \\
\hline Soil class & ZA & ZB & ZC & ZD & ZE & ZA & ZB & ZC & ZD & ZE \\
$\emptyset_{\mathrm{r}}\left({ }^{\circ}\right)$ & 28 & 30 & 34 & 36 & 38 & 28 & 30 & 34 & 36 & 38 \\
$\gamma_{\mathrm{r}}\left(\mathrm{kN} / \mathrm{m}^{3}\right)$ & 16 & 17 & 18 & 19 & 20 & 16 & 17 & 18 & 19 & 20 \\
$\mathrm{FS}_{\mathrm{S}}$ & 0.8 & 1 & 1.2 & 0.9 & 0.8 & 2.4 & 1.6 & 1.3 & 0.9 & 0.8 \\
$\mathrm{~S}_{\mathrm{DS}}$ & 1.2 & 1.5 & 1.8 & 1.35 & 1.2 & 0.6 & 0.4 & 0.325 & 0.225 & 0.2 \\
$\mathrm{SS}_{\mathrm{S}}$ & 0.25 & 0.25 & 0.25 & 0.25 & 0.25 & 1.50 & 1.50 & 1.50 & 1.50 & 1.50 \\
\hline
\end{tabular}

\section{Optimum Design of Cantilever Retaining Wall}

\subsection{Harmony Search Algorithm}

Recently, heuristic methods have been widely used in solving complex optimization problems encountered in the field of engineering. Heuristic methods are algorithms that produce solutions to optimization problems by making use of the solutions produced by nature in the face of difficult problems. The harmony search algorithm was first developed by Geem et al. (2001) [25] and based on the principle of finding the best harmony during music performance. Harmony search algorithm is a more advantageous algorithm than other heuristic methods because of its simple algorithm, it gives results in a reasonable time when the number of iterations is high, it can be used for continuous or discrete variables, and it reaches the global solution without getting stuck with local solutions in the optimization process.

The steps of the harmony search algorithm are given below.

Step 1: In the harmony search algorithm, the algorithm parameters that control the solution process are started. A valid range of values is defined for each design variable in the optimum design problem. By taking these values, a design pool is created for the design variables of the algorithm. Then, the number of solution vectors of the memory matrix (HMS), the memory matrix consideration ratio (HMCR), the adjustment ratio (PAR) between the two values, and the maximum number of iterations of the stopping criterion are selected in this step.

Step 2: The harmony memory matrix (HM) is initialized. Initial values are assigned to the harmony memory matrix. Each row of this matrix contains values randomly selected from the design pool, containing possible solutions for a particular design variable. Here $\mathrm{N}$ corresponds to the number of design variables and the number of rows in the HMS memory matrix. In the harmony memory matrix, the solution vectors are ordered from the minimum to the maximum with the values of the objective functions. Here, not only the possible solution vectors, but also the solution values with small inconveniences are included in the solution matrix.

Step 3: A new harmony memory matrix is developed. In the harmony search method, the creation of a new solution vector is controlled by the two main parameters of this method 
(HMCR and PAR). HMCR is a probability value that directs the algorithm to either the harmony memory or the entire set of values to select a value for a design variable. Sometimes, when the design variable is selected from the harmony memory, it is checked whether this variable replaces its nearest upper and lower neighbors. The aim here is to make a more detailed search by providing transitions around a current solution. This phenomenon in the harmony search method is known as the adjustment (PAR) between two values.

Step 4: The harmony memory matrix is updated. After obtaining new values for each design variable, the objective function value is calculated for the new solution vector. If this value is better than the worst harmonic vector value in the harmony memory matrix, it is included in the matrix and the worst value is removed from the matrix.

Step 5: Repeat Step 3 and Step 4 until the maximum number of cycles, which is the termination criterion, is reached.

In the optimization implementation of the harmony search algorithm for the cantilever retaining wall, HMS, HMCR, and PAR algorithm parameters values have been taken as 20,0.90, and 0.35 , respectively $[25,27]$. The process of reaching the optimum value for each design case has been completed by operating 30,000 maximum iterations that the result did not change with the continued analyzes. Each process with 30,000 iterations has been repeated for 30 independent runs. Deb's rules have been employed in evaluating solutions that have a constraint violation [28].

\subsection{Definition of Optimization Problem}

In the optimum design of CRW, the top stem width $\left(\mathrm{X}_{1}\right)$, the toe extension $\left(\mathrm{X}_{2}\right)$, the bottom stem width $\left(\mathrm{X}_{3}\right)$, the heel extension $\left(\mathrm{X}_{4}\right)$ and base thickness $\left(\mathrm{X}_{5}\right)$ of the wall have been considered as design variables. Because of the design parameters corresponds to the dimensions of CRW, these values and their intervals have been selected as discrete values. The lower and upper limits of the design variables shown in Figure 3 are given in Table 3. 


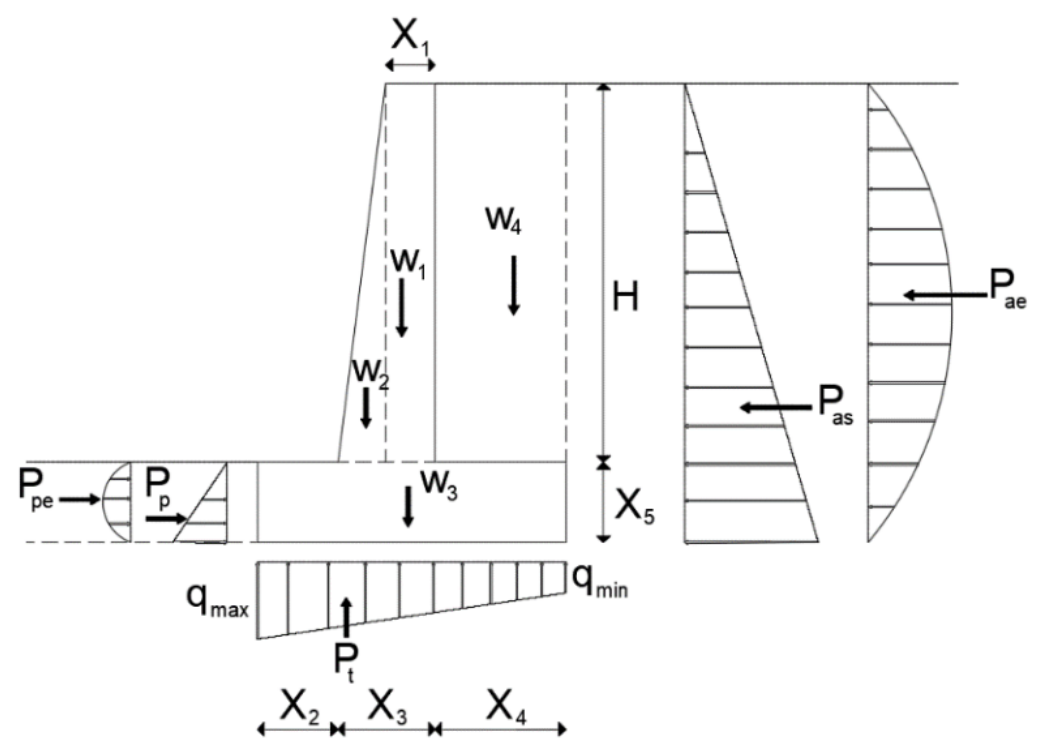

Fig. 3. CRW optimum design problem with design variables and acting loads on the wall $[20,21]$

Table 3. Discrete design variable values for CRW

\begin{tabular}{cccc}
\hline Design variable & Lower limit & Upper limit & Increment \\
\hline $\mathrm{X}_{1}$ & $0.30 \mathrm{~m}$ & $0.60 \mathrm{~m}$ & $2 \mathrm{~cm}$ \\
$\mathrm{X}_{2}$ & $0.30 \mathrm{~m}$ & $3.00 \mathrm{~m}$ & $5 \mathrm{~cm}$ \\
$\mathrm{X}_{3}$ & $0.30 \mathrm{~m}$ & $0.60 \mathrm{~m}$ & $2 \mathrm{~cm}$ \\
$\mathrm{X}_{4}$ & $0.30 \mathrm{~m}$ & $3.00 \mathrm{~m}$ & $5 \mathrm{~cm}$ \\
$\mathrm{X}_{5}$ & $0.50 \mathrm{~m}$ & $1.00 \mathrm{~m}$ & $2 \mathrm{~cm}$ \\
\hline
\end{tabular}

The design constraints used to meet the stability criteria of the wall in the optimization analyses in terms of obtaining both safe and optimum design are given in Table 4.

Table 4. Considering constraints in optimization analyses

\begin{tabular}{cc}
\hline Constraint & Mathematical definition \\
\hline Sliding check for static case & $g_{x}(1)=1-F_{s s} / 1.50 \leq 0$ \\
Overturning check for static case & $g_{x}(2)=1-F_{d s} / 1.50 \leq 0$ \\
Bearing capacity check for static & $g_{x}(3)=1-\frac{q_{u}}{3 q_{\max }} \leq 1$ \\
case & $g_{x}(4)=\frac{6 e}{X_{2}+X_{3}+X_{4}} \leq 1$ \\
Sliding check for dynamic case \\
Overturning check for dynamic \\
case \\
Bearing capacity check for \\
dynamic case \\
Geometric 1 \\
Geometric 2 \\
$g_{x}(6)=1-\frac{R_{\text {the }}}{1.3 E_{d e v}} \leq 0$ \\
$g_{x}(7)=1.4 q_{0} / q_{u}-1 \leq 0$ \\
\end{tabular}

The objective function considered in the investigation of the minimum wall cost based on the wall weight is given in Equation 9. 


$$
f_{\min }=\left(W_{1}+W_{2}+W_{3}\right) \gamma_{c} c_{c}
$$

\section{Results of Optimization Analyses}

Investigation of the cantilever retaining wall (CRW) optimum design for different soil classes (ZA, ZB, ZC, ZD, ZE) and earthquake loads $(\mathrm{Ss}=0.25,1.50)$ have been performed via HSA. Obtained optimum designs for ten design cases and design variables tabulated in Table 1 and Table 3, respectively have been presented in this section.

After the optimization algorithm of HSA was operated with 30 independent runs, the optimum designs were obtained the most minimum objective function value among all runs. Obtained CRW designs which are satisfied design constraints for all runs are showed in Fig. 4 for $\mathrm{S}_{\mathrm{s}}=0.25$ and in Fig. 5 for $\mathrm{S}_{\mathrm{S}}=1.50 . \mathrm{X}_{1}, \mathrm{X}_{2}, \mathrm{X}_{3}, \mathrm{X}_{4}$ and $\mathrm{X}_{5}$ wall dimensions and the wall weights have been compared in terms of different design cases.

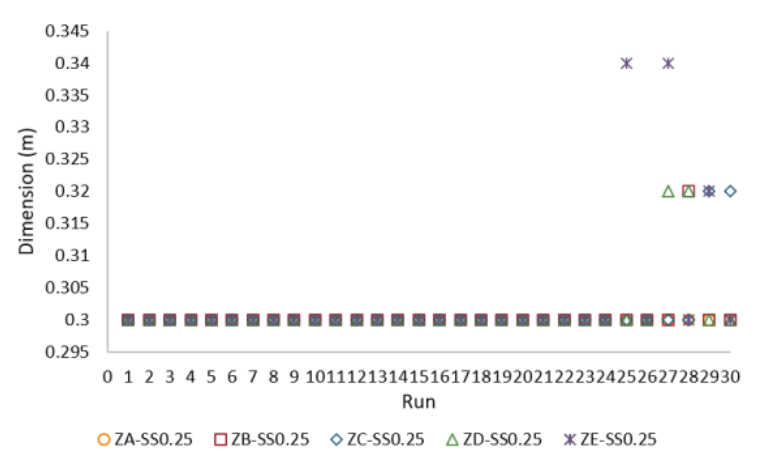

(a)

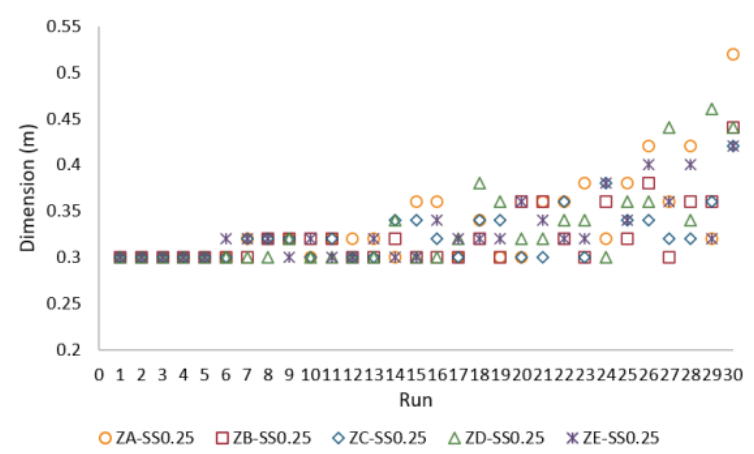

(c)

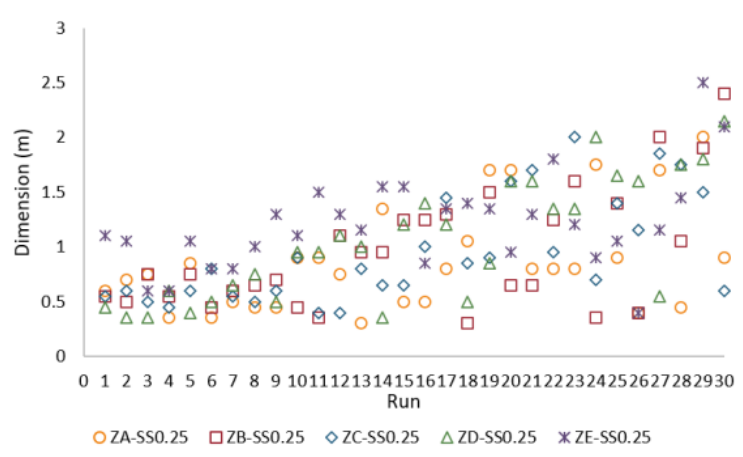

(b)

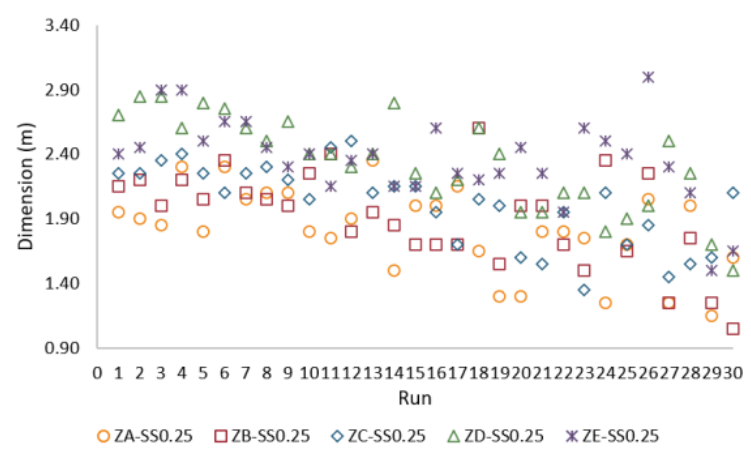

(d) 


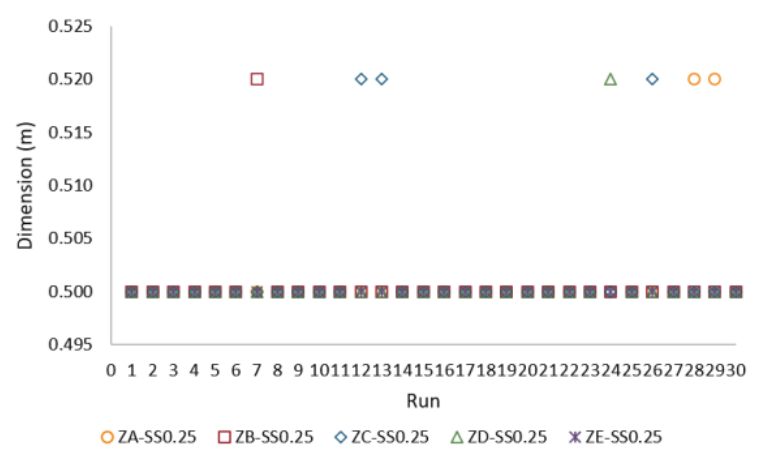

(e)

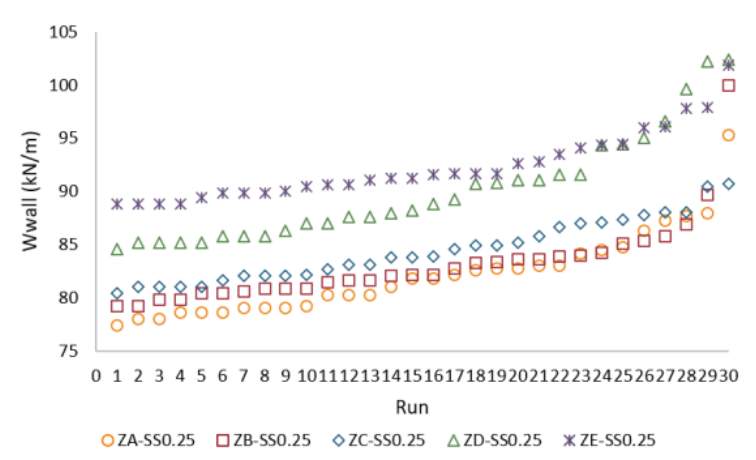

(f)

Fig.4. Results of optimization analyses for case $\mathrm{S}_{\mathrm{S}}=0.25$ : (a) $\mathrm{X}_{1}$; (b) $\mathrm{X}_{2}$; (c) $\mathrm{X}_{3}$; (d) $\mathrm{X}_{4}$; (e) $\mathrm{X}_{5}$; (f) $\mathrm{W}_{\text {wall }}$

It has been observed from Fig.4(a) and Fig.5(a), there was no significant change in the top stem width $\left(\mathrm{X}_{1}\right)$ values, even if the soil properties and earthquake effect changed. Similar linear behavior like $\mathrm{X}_{1}$ has been seen for the base thickness $\left(\mathrm{X}_{5}\right)$ in Fig.4(e) and Fig.5(e). When the graphs, which are given in Fig.4 (b) and Fig.4 (d) for toe extension $\left(\mathrm{X}_{2}\right)$ and heel extension $\left(\mathrm{X}_{4}\right)$, respectively have been examined, it has been seen that the wall dimensions are mostly changeable in soils with different properties and effects of distinctive earthquake loads. Although $\mathrm{X}_{4}$ has changing ground characteristics like $\mathrm{X}_{2}$ and differing behavior under earthquake effect, it is observed that the wall weight has been boosted with decreasing $\mathrm{X}_{4}$ values and increasing $\mathrm{X}_{2}$ values. The bottom stem width $\left(\mathrm{X}_{3}\right)$ values have changeable behavior for different design cases. For $\mathrm{X}_{2}$ and $\mathrm{X}_{4}$, there is a more linear variation in Fig.5(c) than in Fig.4(c) in terms of different soil environment and different earthquake effects. It is observed that each wall dimension has almost same value in case of $\mathrm{Ss}=1.5$ and $\mathrm{ZC}$ which exposed to larger earthquake effect than the other design cases. According to Fig.5(f), it is concluded that more different wall design satisfying design constraints has not been found due to obtaining same wall weight.

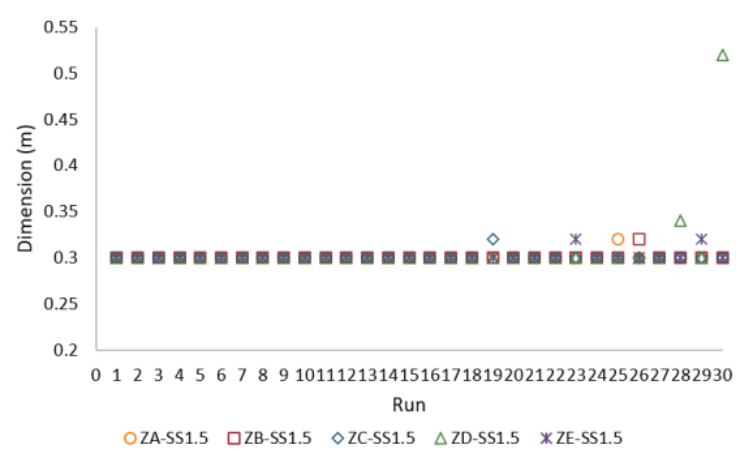

(a)

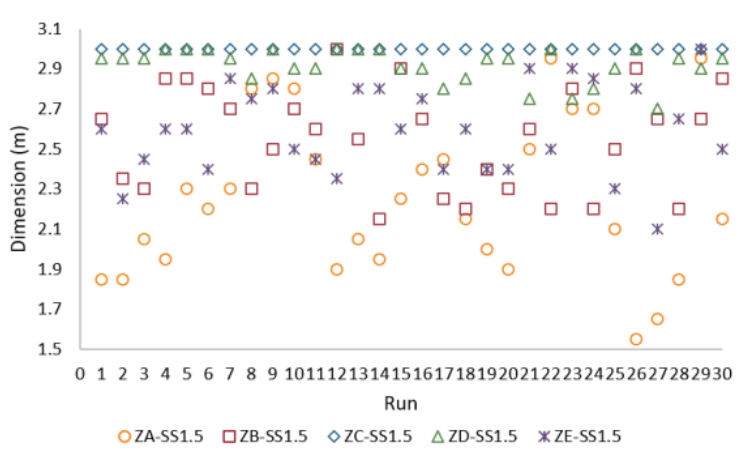

(b) 


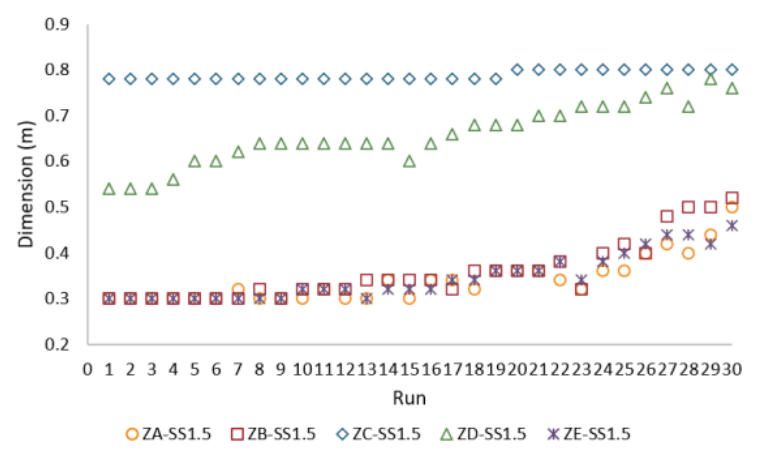

(c)

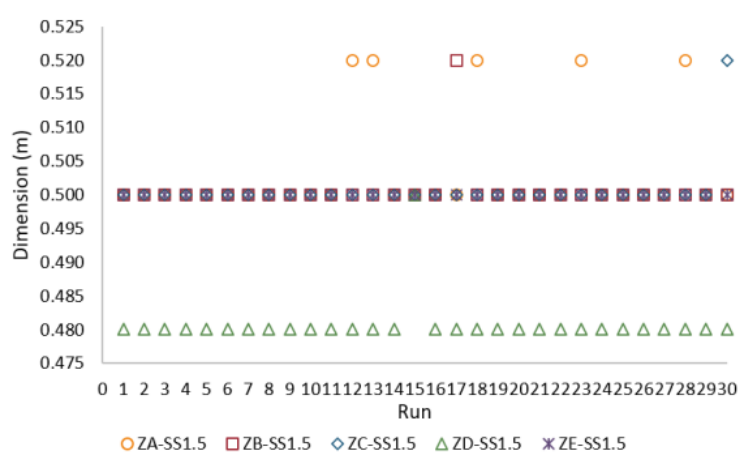

(e)

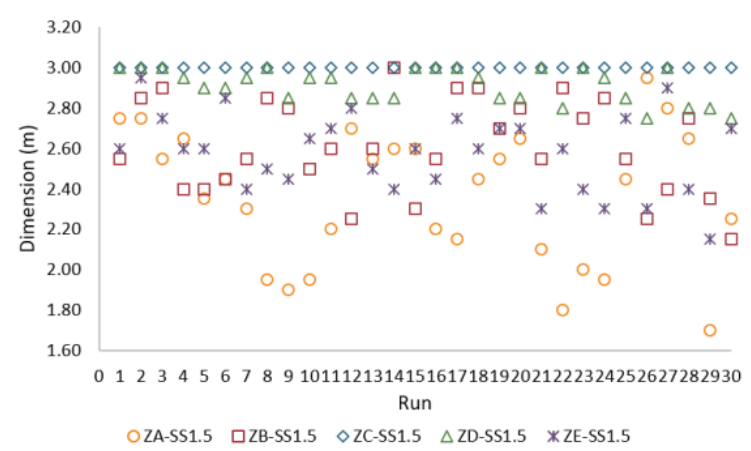

(d)

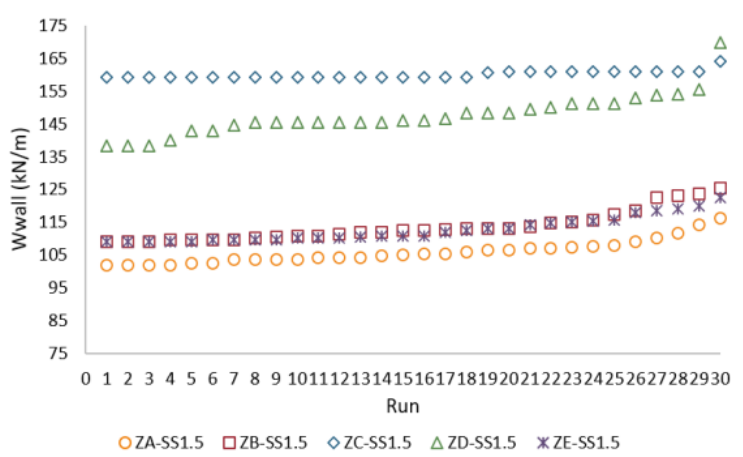

(f)

Fig.5. Results of optimization analyses for case $\mathrm{S}_{\mathrm{S}}=1.50$ : (a) $\mathrm{X}_{1}$; (b) $\mathrm{X}_{2}$; (c) $\mathrm{X}_{3}$; (d) $\mathrm{X}_{4}$; (e) $\mathrm{X}_{5}$; (f) $\mathrm{W}_{\text {wall }}$

The optimum designs which provide all the constraints and have the most minimum objective function value are given in Fig. 6 for the wall weight, cost, and dimensions. In the optimization analyses, since the feasible design were not obtained for $\mathrm{Ss}=1.50$ and $\mathrm{ZC}$ design case, the results of the feasible design for the design case considering $\varnothing \mathrm{d}=40^{\circ}$ have been presented. It is due to the dynamic effect being much for $\mathrm{Ss}=1.50$ and $\mathrm{ZC}$ design case.

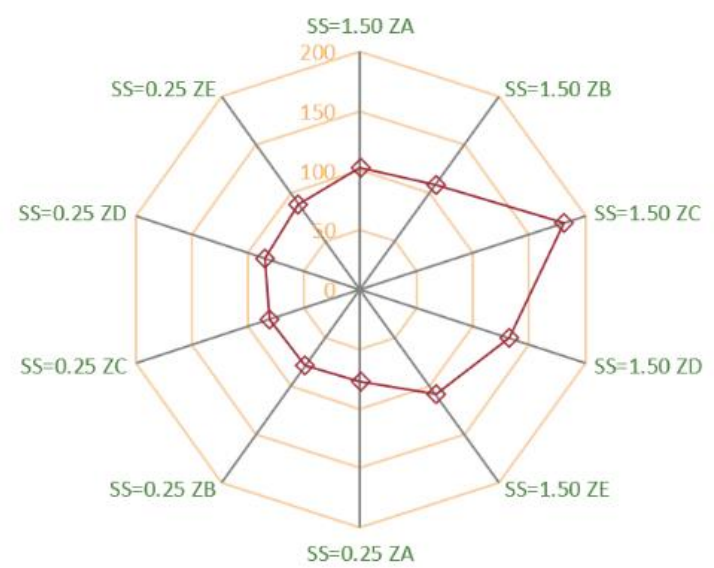

(a)

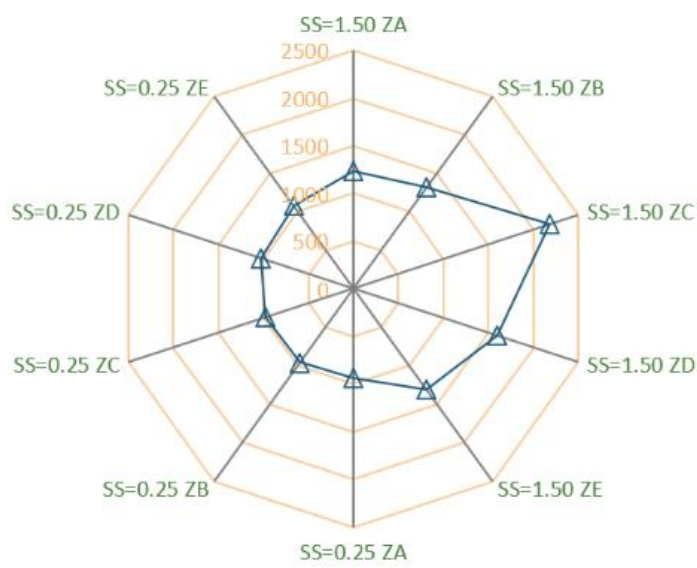

(b) 


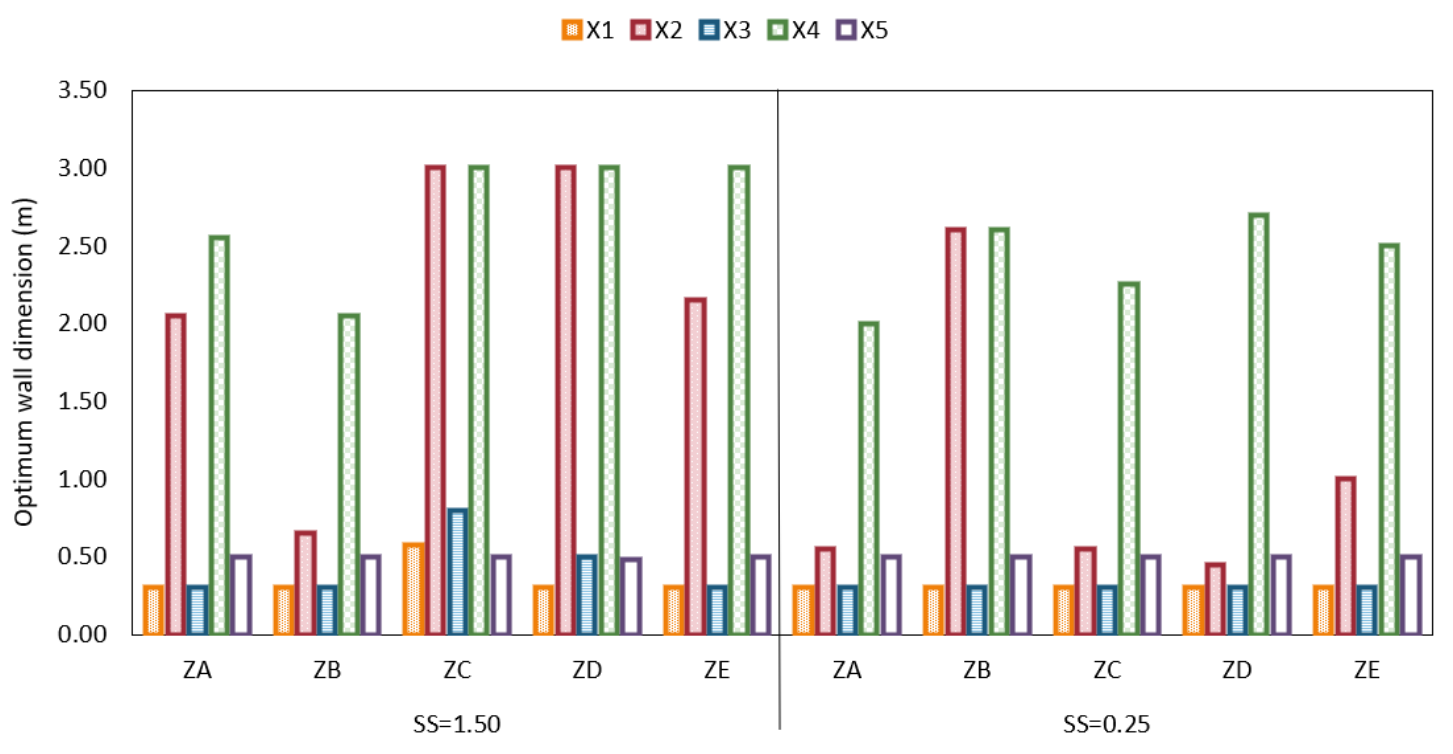

(c)

Fig.6. Optimum CRW designs for difeerent soil classes and SS values: (a) Weight $(\mathrm{kN} / \mathrm{m})$;

(b) Cost (TL/m); (c) Wall dimesions

According to Fig.6 (a) and (b), it is seen that the wall costs in the case with a strong earthquake effect $\left(\mathrm{S}_{s}=1.50\right)$ increase compared to the case with less earthquake effect $\left(\mathrm{S}_{s}=0.25\right)$ in terms of different earthquake zones and soils. Providing the stability criteria for dynamic loading, which considers the effect on the wall in case of the earthquake, is possible by increasing the wall dimensions. When the results are evaluated in terms of different soil properties, it is observed that the cost increases from good quality soil to poor quality soil (from ZA to ZE) for $\mathrm{Ss}=0.25$, while a similar trend is observed from $\mathrm{ZA}$ to $\mathrm{ZC}$ for $\mathrm{Ss}=1.50$. It was observed in Fig.6 (b) that there was a $36 \%$ change between the maximum and minimum costs for $\mathrm{Ss}=1.50$ and $12 \%$ for $\mathrm{Ss}=0.25$. When the wall dimensions given in Fig.6 (c) are examined considering all design cases which are included different soil properties and earthquake effects, no significant change is observed in the values the top stem width $\left(\mathrm{X}_{1}\right)$, the bottom stem width $\left(\mathrm{X}_{3}\right)$, and base thickness $\left(\mathrm{X}_{5}\right)$. It is seen that the major change of wall dimensions has occurred in the toe extension $\left(\mathrm{X}_{2}\right)$ and the heel extension $\left(\mathrm{X}_{4}\right)$ of the wall base, especially in $\mathrm{SS}=1.50$ and ZC-ZD design cases.

Iteration graphs of optimization analyses for case $\mathrm{S}_{\mathrm{S}}=0.25$ and $\mathrm{S}_{\mathrm{S}}=1.50$ have been demonstrated in Fig.7 and Fig.8, respectively. Design constraints of the optimum designs for CRW design which provide stability criteria are given in Table 5. 

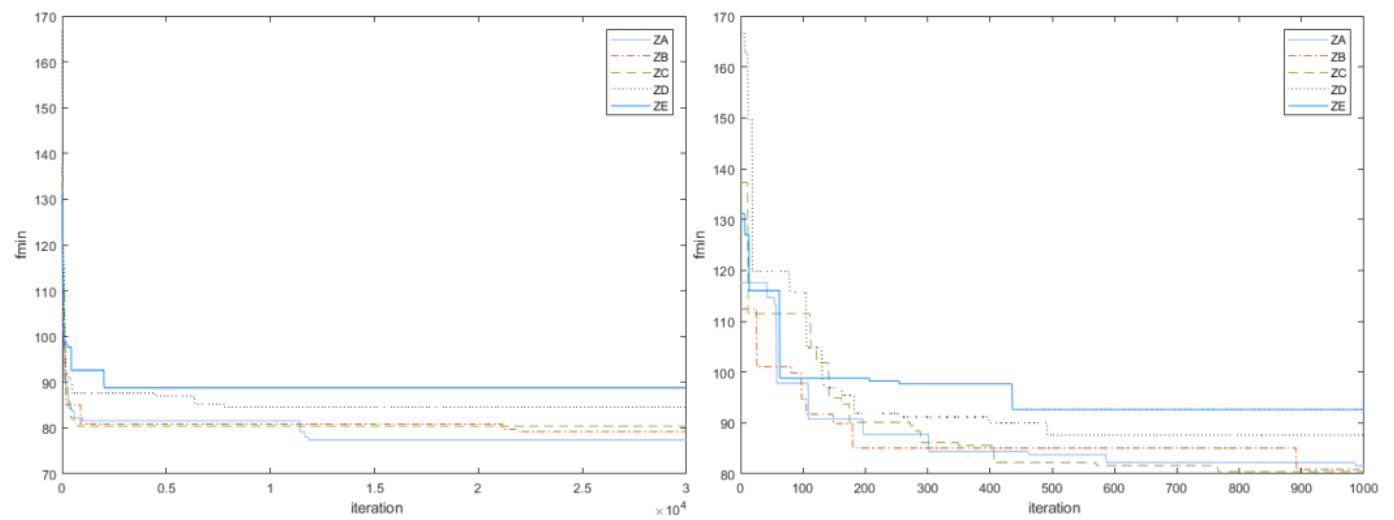

Fig.7. Iteration history graphs for $\mathrm{S}_{\mathrm{S}}=0.25$ : (a) Weight $(\mathrm{kN} / \mathrm{m})$; (b) Cost $(\mathrm{TL} / \mathrm{m})$; (c) Wall dimesions
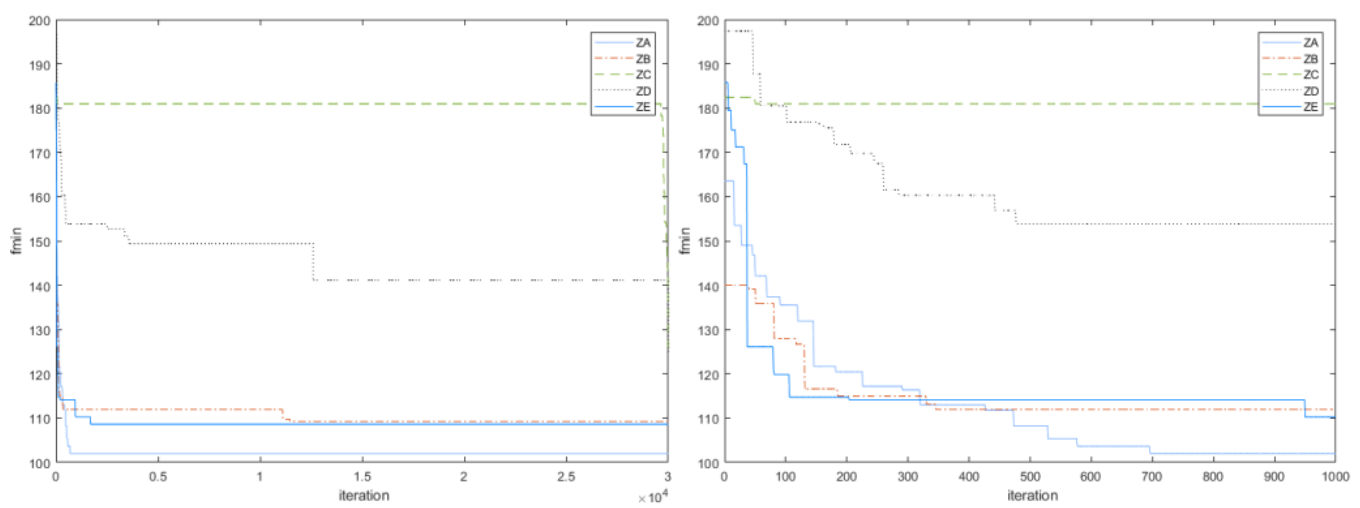

Fig.8. Iteration history graphs for $\mathrm{S}_{\mathrm{S}}=1.50$ : (a) Weight (kN/m); (b) Cost (TL/m); (c) Wall dimesions

Table 5. Constraints values of optimum designs

\begin{tabular}{c|ccccc|ccccc}
\hline $\mathrm{S}_{\mathrm{S}}$ & \multicolumn{6}{c}{1.50} & & \multicolumn{3}{c}{0.25} \\
Constraint & ZA & ZB & ZC & ZD & ZE & ZA & ZB & ZC & ZD & ZE \\
\hline $\mathrm{g} 1(\mathrm{x})$ & -0.56 & -0.625 & -1.49 & -0.636 & -0.369 & -0.014 & -0.003 & -0.004 & -0.004 & -0.01 \\
$\mathrm{~g} 2(\mathrm{x})$ & -3.18 & -3.563 & -7.40 & -4.093 & -2.568 & -0.601 & -0.62 & -0.62 & -0.73 & -0.88 \\
$\mathrm{~g} 3(\mathrm{x})$ & -17.25 & -53.36 & -172.84 & -30.66 & -19.69 & -10.37 & -3.93 & -9.91 & -2.14 & -3.60 \\
$\mathrm{~g} 4(\mathrm{x})$ & -1.39 & -1.549 & -1.80 & -1.592 & -1.194 & -0.024 & -0.07 & -0.004 & -0.01 & -0.32 \\
$\mathrm{~g} 5(\mathrm{x})$ & -0.72 & -0.726 & -0.70 & -0.710 & -0.734 & -0.811 & -0.81 & -0.79 & -0.77 & -0.76 \\
$\mathrm{~g} 6(\mathrm{x})$ & -0.004 & -0.005 & -0.001 & -0.005 & -0.005 & -0.306 & -0.29 & -0.13 & -0.12 & -0.02 \\
$\mathrm{~g} 7(\mathrm{x})$ & -0.97 & -0.986 & -0.99 & -0.974 & -0.980 & -0.985 & -0.96 & -0.98 & -0.94 & -0.95 \\
$\mathrm{~g} 8(\mathrm{x})$ & -0.52 & -0.473 & -0.442 & -0.462 & -0.550 & -0.702 & -0.68 & -0.72 & -0.78 & -0.65 \\
$\mathrm{~g} 9(\mathrm{x})$ & 0.000 & 0.000 & -0.615 & -0.400 & 0.000 & 0.000 & 0.000 & 0.000 & 0.000 & 0.000 \\
\hline
\end{tabular}

\section{Discussion}

The results obtained for the optimal design of the CRW by using HSA have been compared with the studies in the literature, which is presented with different heuristic optimization algorithms for the same optimization problem as this study. While the modified artificial bee colony algorithm (MABC) study has more minimum wall weight and cost, the particle swarm optimization (PSO) study has almost the same values by comparison with optimum designs with HSA according to results of optimum CRW design obtained by considering the MABC [20] and the particle swarm optimization (PSO) [21] for the same design cases. It has been observed similarly that the optimum design that provides the design constraints for $\varnothing \mathrm{d}=34^{\circ}$ in 
the case of $\mathrm{ZC}$ and $\mathrm{SS}=1.5$ could not be obtained, due to the large impacting earthquake load and different soil characteristics.

The optimum weight of the cantilever retaining wall by HSA has been obtained as $\mathrm{W}_{\text {wall }}=$ $59.4 \mathrm{kN} / \mathrm{m}$ for $\varnothing_{\mathrm{r}}=40^{\circ}$ and $\gamma_{\mathrm{r}}=18 \mathrm{kN} / \mathrm{m}^{3}$ with considering static load case in another literature study [29]. For the same design case, the optimum wall weight has been obtained as $181 \mathrm{kN} / \mathrm{m}$ with considering dynamic loads in this study $\left(\varnothing_{\mathrm{r}}=40^{\circ}\right.$ and $\left.\gamma_{\mathrm{r}}=18 \mathrm{kN} / \mathrm{m}^{3}\right)$. This result shows that wall weight accordingly wall dimension has increased in order to provide design criteria (constraints) for additional loads like dynamic effect. That's why optimization analyses in this kind of design problem may be an alternative manner for obtaining more economic design in the wall design.

\section{Conclusions}

In this study, the harmony search algorithm (HSA) has been utilized in order to obtain the optimum design of the cantilever retaining wall (CRW) and the minimum wall weight for different design cases. Besides, the effect of different soil properties and earthquake loads on the wall weight and wall dimensions have been investigated.

According to the optimization analyzes results, when the map spectral acceleration coefficient (Ss) taken from TERM and expressing the seismicity effect of the region is 1.50 , it is seen that the CRW design has the highest cost for ZC type soil from among the design situations. Another remarkable result is that $\mathrm{ZD}$ and $\mathrm{ZE}$, which have worse soil properties than $\mathrm{ZC}$, have lower costs under the same earthquake effect. Since the characteristics of the earthquake wave that occurred in the earth and transmitted to the structure through the soil changes depending on the different soil properties, and the dynamic earthquake behavior should be evaluated within its specific structure in the designs to be made in different soil environments. As a result, obtaining larger dimensions due to safely meet the loads caused by the earthquake effect in the structure has been shown that performing optimization analyses based on heuristic algorithms is important for the most economical and safe design in the current design cases.

It has been concluded that HSA is an alternative method in obtaining CRW optimum design which is a complex engineering design problem with many unknowns under effect both static and dynamic loads. For different design cases which included many design parameters, the heuristic optimization algorithms can be utilized safely and effectively in the examination of parameter effects on the target goals like cost, design criteria, and so on.

\section{References}

[1] Das Braja M. S.K., Principles of Foundation Engineering (9th Edition). Cengage Learning, 2017

[2] Uray, E., Tan, Ö., Çarbaş, S., Erkan, H., Metaheuristics-based pre-design guide for cantilever retaining walls, Teknik Dergi, 32, 2021. doi:10.18400/tekderg.561956

[3] Carbas, S., Toktas, A., Ustun, D.editors, Nature-Inspired Metaheuristic Algorithms for Engineering Optimization Applications. Springer Singapore, 2021. doi:10.1007/978-981- 
$33-6773-9$

[4] Uray, E., Carbas, S., Erkan, I.H., Tan, O., Parametric investigation for discrete optimal design of a cantilever retaining wall, Challenge Journal of Structural Mechanics, 5, 108, 2019. doi:10.20528/cjsmec.2019.03.004

[5] Kalemci, E.N., İkizler, S.B., Dede, T., Angın, Z., Design of reinforced concrete cantilever retaining wall using Grey wolf optimization algorithm, Structures, 23, 245-53, 2020. doi:10.1016/j.istruc.2019.09.013

[6] Temür, R., Bekdas, G., Teaching learning-based optimization for design of cantilever retaining walls, Structural Engineering and Mechanics, 57, 763-83, 2016

[7] Akin, A., Saka, M.P., Optimum design of concrete cantilever retaining walls using the harmony search algorithm, Civil-Comp Proceedings, 93, 1-21, 2010. doi:10.4203/ccp.93.130

[8] Temur, R., Bekdas, G., Temür, R., Bekdaş, G., Teaching Learning-Based Optimization for Design of Cantilever Retaining Walls Design and analysis of nonlinear structural systems View project Teaching learning-based optimization for design of cantilever retaining walls, Structural Engineering and Mechanics, 57, 763-83, 2016. doi:10.12989/sem.2016.57.4.763

[9] Dağdeviren, U., Kaymak, B., Investigation of parameters affecting optimum cost design of reinforced concrete retaining walls using artificial bee colony algorithm, Journal of the Faculty of Engineering and Architecture of Gazi University, 33, 239-53, 2018. doi:10.17341/gazimmfd.406796

[10] Gandomi, A.H., Kashani, A.R., Zeighami, F., Retaining wall optimization using interior search algorithm with different bound constraint handling, International Journal for Numerical and Analytical Methods in Geomechanics, 41, 1304-31, 2017. doi:10.1002/NAG.2678

[11]T.C. Resmi Gazete., Turkish Building Earthquake Code (Türkiye Bina Deprem Yönetmeliği)-2018 (TBEC-18). 2018

[12] Arslan, Ö., Keskin, I., Ateş, A., Farklı deprem yüklerinin betonarme konsol bir istinat duvarının maliyetine etkisinin analizi, Anadolu Üniversitesi Bilim ve Teknoloji Dergisi - B Teorik Bilimler, 6, 28-35, 2018. doi:10.20290/aubtdb.497527

[13]Bilgin, H., İstinat duvarlarının dinamik ve statik yükler altındaki davranışının analizi. Karadeniz Teknik University, Department of Civil Engineering, Master Thesis, 2006

[14]Dalyan, İ., Akın, M., Akbay Arama Z., Betonarme istinat duvarlarının geoteknik tasarımında etkili parametrelerin 2018 Türkiye Bina Deprem Yönetmeliği'ne göre değerlendirilmesi, Türk Deprem Araştırma Dergisi, 2, 176-92, 2020. doi:10.46464/tdad.80428

[15] Yıldırım, İ.Z., İstinat duvarlarının tasarımında deprem etkilerinin incelenmesi. İstanbul Teknik University, Department of Civil Engineering, Master thesis, 2004

[16] Aydogdu, I., Cost optimization of reinforced concrete cantilever retaining walls under 
seismic loading using a biogeography-based optimization algorithm with Levy flights, Taylor \& Francis, 49, 381-400, 2017. doi:10.1080/0305215X.2016.1191837

[17]Kayhan, A., Demir, A., Statik ve dinamik yüklere maruz betonarme konsol istinat duvarlarının diferansiyel gelişim algoritması ile optimum tasarımı, Pamukkale Üniversitesi Mühendislik Bilimleri Dergisi, 24, 403-12, 2018. doi:10.5505/pajes.2017.04834

[18]Ravichandran, N., Wang, L., Rahbari, P., Juang, C.H., Robust design optimization of retaining wall backfilled with shredded tire in the face of earthquake hazards, Bulletin of Engineering Geology and the Environment, 80, 1351-63, 2021. doi:10.1007/s10064-02002038-9

[19] Kaveh, A., Akbari, H., Hosseini, S.M., Plasma generation optimization for optimal design of reinforced concrete cantilever retaining wall structures, Iranian Journal of Science and Technology - Transactions of Civil Engineering, 2021. doi:10.1007/s40996-020-00566-8

[20]Uray, E., Çıtırık, B.N., Modifiye Yapay Arı Kolonisi Algoritması ile konsol dayanma duvarının Türkiye Bina Deprem Yönetmeliği 2018' e göre optimum tasarımı, Avrupa Bilim ve Teknoloji Dergisi, 26, 61-7, 2021. doi:10.31590/ejosat.948040

[21]Uray, E., Çarbaş, S., Parçacık Sürü Optimizasyonu ile konsol dayanma duvarının Türkiye Bina Deprem Yönetmeliği-2018'e göre optimum tasarımı. In: Özkaya U, editor. 1st Int. Conf. Appl. Eng. Nat. Sci., 2021. doi:ISBN: 978-625-00-0389-3

[22] Afzal, M., Liu, Y., Cheng, J.C.P., Gan, V.J.L., Reinforced concrete structural design optimization: A critical review, Journal of Cleaner Production, 260, 120623, 2020. doi:10.1016/J.JCLEPRO.2020.120623

[23] Kalyoncuoğlu, Ü.Y., Depreme dayanıklı yapılanma için zemin sınıfları ve ivme tepkileri (Tayvan örneği), Süleyman Demirel Üniversitesi Fen Bilimleri Enstitüsü Dergisi, 10, 42836, 2006

[24] TDTH., Turkey Earthquake Hazard Map (TERM) (Türkiye Deprem Tehlike Haritaları), 2018. https://tdth.afad.gov.tr/TDTH/main.xhtml

[25] Geem, Z., Kim, J., Loganathan, G., A new heuristic optimization algorithm: harmony search, Simulation, 76, 60-8, 2001. doi:10.1177/003754970107600201

[26] Meyerhof, G.G., Some recent research on the bearing capacity of foundations, Canadian Geotechnical Journal, 1, 16-26, 1963. doi:10.1139/t63-003

[27]Lee, K., Geem, Z., A new meta-heuristic algorithm for continuous engineering optimization: harmony search theory and practice, Computer Methods in Applied Mechanics and Engineering, 194, 3902-33, 2005. doi:10.1016/j.cma.2004.09.007

[28]Deb, K., An efficient constraint handling method for genetic algorithms, Computer Methods in Applied Mechanics and Engineering, 186, 311-38, 2000. doi:10.1016/S00457825(99)00389-8

[29]Uray, E., Çarbaş, S., Erkan, İ.H., Tan, Ö., Parametric investigation for discrete optimal design of a cantilever retaining wall, Challenge Journal of Structural Mechanics, 5, 108, 2019. doi:10.20528/cjsmec.2019.03.004 